\title{
Regulation of Innate Immune Function in Bovine Oviduct Epithelial Cells in Culture: The Homeostatic Role of Epithelial Cells in Balancing Th1/Th2 Response
}

\author{
Rasoul KOWSAR ${ }^{1)}$, Nina HAMBRUCH ${ }^{2}$, Jinghui LIU1), Takashi SHIMIZU1), \\ Christiane PFARRER ${ }^{2)}$ and Akio MIYAMOTO' \\ ${ }^{1)}$ Graduate School of Animal and Food Hygiene, Obihiro University of Agriculture and Veterinary Medicine, Hokkaido \\ 080-8555, Japan \\ ${ }^{2)}$ Department of Anatomy, University of Veterinary Medicine Hannover, Hannover D-30173, Germany
}

\begin{abstract}
This study aimed to investigate the role of epithelial cells in regulating innate immunity in bovine oviduct epithelial cell (BOEC) culture. We studied the effect of Escherichia coli lipopolysaccharide (LPS) and its interaction with ovarian steroids, estradiol (E2) and progesterone (P4), and luteinizing hormone (LH) at concentrations observed during the preovulatory period on immune responses in BOEC culture. Immunohistochemistry of oviduct tissue showed intensive expression of Toll-like receptor-4 (TLR-4) and TLR-2 in epithelial cells. A dose of $10 \mathrm{ng} / \mathrm{ml}$ LPS stimulated TLR-4, cyclooxygenase-2 (COX-2), nuclear factor kappa B inhibitor A (NFKBIA), interleukin $1 \beta(I L-1 \beta)$ and tumor necrosis factor $\alpha(T N F-\alpha)$ expression, indicating an early pro-inflammatory response. A dose of $100 \mathrm{ng} / \mathrm{ml} \mathrm{LPS} \mathrm{did} \mathrm{not} \mathrm{induce} \mathrm{expression} \mathrm{of}$ these genes but stimulated TLR-2, IL-10, IL-4 and microsomal prostaglandin E synthase-1 (mPGES-1) expression and PGE2 secretion, indicating an anti-inflammatory response. Ovarian steroids and LH completely block LPS (10 ng/ml)-induced TLR$4, I L-1 \beta$ and $T N F-\alpha$ expression as well as LPS (100 ng/ml)-induced $T L R-2$ expression. Taken together, this study suggests the existence of an early signaling system to respond to infection in the BOEC. In addition, ovarian steroids and LH may play a critical role in inducing homeostasis and in controlling hyperactive pro-inflammatory responses detrimental to epithelial cells, sperm and the embryo.
\end{abstract}

Key words: Bovine oviduct epithelial cell, Ovarian steroids, TLR-4, Th1/Th2 response

(J. Reprod. Dev. 59: 470-478, 2013)

$\mathbf{T}$ he mammalian oviduct provides an optimal microenvironment for the activation and transportation of gametes, sperm capacitation, fertilization and early embryonic development, which is critical for the establishment of a successful pregnancy [1]. The oviduct is classically described as a sterile milieu even though pathogens and endotoxins can invade the mucosal surfaces of the oviduct via the uterus, peritoneal cavity and follicular fluid [2]. Therefore, the oviduct should be equipped with an efficient and strictly controlled immune system that would maintain optimal conditions for fertilization and early embryo development. Local immune responses, regulated by the secretions of epithelial cells, form a part of the mucosal innate immunity. In recent years, these responses, termed the epimmunome [3], have been recognized as critically important defense mechanisms, and their significance seems far greater than that of the systemic immune responses. The direct response of epithelial cells to microbial (i.e., pathogens) or nonmicrobial (i.e., stress or hormones) stimuli includes activation of the innate immune responses and regulation of subsequent adaptive immune responses [4]. This process is mediated by the secretion of different molecules

Received: April 4, 2013

Accepted: May 21, 2013

Published online in J-STAGE: June 21, 2013

C 2013 by the Society for Reproduction and Development

Correspondence: A Miyamoto (e-mail: akiomiya@obihiro.ac.jp) such as prostaglandins, chemokines and cytokines, which affect the conditioning of mucosal dendritic cells (DCs) [5]. Therefore, mucosal epithelial cells can orchestrate and provide early signals to drive immunity toward tolerance or inflammation.

The innate immune system recognizes pathogen-associated molecular patterns (PAMPs) using pattern recognition receptors (PRRs) such as Toll-like receptors (TLRs) [6, 7]. At least 10 bovine TLRs have been identified [8], and these PRRs bind to a range of microbial products and endogenous ligands. TLR signals are involved in the primary induction of inflammation as well as in the secondary activation of anti-inflammatory mechanisms [9]. For example, TLR-4 is a signal transducer of LPS, a component of the outer membrane of gram-negative bacteria. Ligation of TLR-4 by LPS leads to activation of nuclear factor kappa $\mathrm{B}(\mathrm{NF}-\mathrm{\kappa} \mathrm{B})$ and consequently transcription of pro-inflammatory cytokines and chemokines [10]. Another member of the TLR family, TLR-2, recognizes PAMPs associated with both gram-negative and gram-positive bacteria, including lipopeptides/ lipoproteins, lipoteichoic acid, zymosan and components of peptidoglycan [11]. E. coli LPS enhances TLR-2 mRNA and cell surface TLR-2 in the mouse [12], human [13, 14] and bovine [15] in an

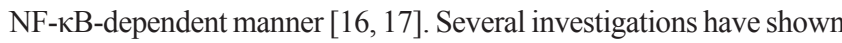
the involvement of TLR-2 in LPS signaling [18, 19]. Engagement of TLR-2 in DCs by the bacterial lipopeptide Pam3Cys enhances extracellular signal-regulated kinase activation, resulting in stabilization of the transcription factor C-FOS, a suppressor of Th1 cytokines [20]. 
The oviduct is exposed to the female sex hormones, and these hormones clearly influence the immune system [21]. The bovine oviduct and BOEC express receptors for LH [22], E2 and P4 [23]. Estradiol and $\mathrm{P} 4$ have been shown to completely block $E$. coli-induced $\mathrm{I} \kappa \mathrm{B} \alpha$ phosphorylation and NF- $\kappa \mathrm{B}$ nuclear translocation in human cord blood mononuclear cells [24]. Sex hormones exert control over many chemokines/cytokines in the female reproductive tract. For example, P4 withdrawal results in increased expression of MCP-1 and IL-8, leading to chemotaxis and activation of monocytes and neutrophils, which results in release and activation of matrix metalloproteinases and initiation of menstruation [25].

It is clear that any changes in the balance between pro-inflammatory and anti-inflammatory responses (Th1 vs. Th2) during infection or a particular physiological situation can contribute to low defense against infection, resulting in increasing susceptibility to infection or low tolerance to pathogens. This, in turn, allows a cytotoxic immune response to be generated against antigens present on the normal epithelium cells, allogeneic sperm and a new semi-allogeneic embryo. It is therefore hypothesized that the BOEC can differentially respond to pathophysiological (i.e., LPS) and physiological (i.e., sex hormones) stimuli through the secretion of different cytokines and chemokines and the use of specific receptors, TLR-4 and TLR-2. We therefore investigated the regulation of local immune responses, Th1- or Th2- type responses, induced by E. coli LPS, ovarian steroids and $\mathrm{LH}$ at the levels around ovulation and their interactions in the BOEC in vitro.

\section{Materials and Methods}

\section{Primary bovine oviduct epithelial cell (BOEC) isolation and culture}

Epithelial cells were isolated as previously described [26, 27]. Briefly, fifteen oviducts were transported in an ice box from the local slaughterhouse to the laboratory, with the oviducts immersed in phosphate-buffered saline (PBS) solution without $\mathrm{Ca}^{2+} / \mathrm{Mg}^{2+}\left(\mathrm{PBS}^{-/-}\right)$ (Sigma, St. Louis, MO, USA) but with $0.3 \%$ gentamicin (Sigma) and amphotericin B (Illkirch, Graffenstaden, France). They were cut and separated from the connective tissue, pathologically found to be healthy and washed twice with PBS. The lumen of oviducts was flushed with $15 \mathrm{ml}$ PBS. BOECs were mechanically dislodged while being flushed with the same volume of PBS. Over a period of $15 \mathrm{~min}$, the pooled sheets of BOECs from 2-3 cows settled at the bottom of the tube, and the cells were then washed with PBS followed by a medium consisting of D-MEM/F12, $0.1 \%$ gentamicin, $1 \%$ amphotericin and $2.2 \% \mathrm{NaHCO}_{3}$. Thereafter, the cells were harvested by centrifugation at $300 \mathrm{~g}$ for $10 \mathrm{~min}$ at $4 \mathrm{C}$. The resultant cell pellet was suspended in $10 \mathrm{ml}$ PBS, layered over $10 \mathrm{ml}$ Percol and centrifuged at $900 \mathrm{~g}$ for $20 \mathrm{~min}$ at $4 \mathrm{C}$. Finally, the cell pellet was washed once with the abovementioned medium, harvested by centrifugation at $300 \mathrm{~g}$ for $10 \mathrm{~min}$ at $4 \mathrm{C}$, and cultured in culture medium (D-MEM/F12, $0.1 \%$ gentamicin, $1 \%$ amphotericin and $2.2 \% \mathrm{NaHCO}_{3}$ supplemented with $10 \%$ fetal calf serum [FCS; BioWhittaker, Walkersville, MD, USA]) in 6-well culture dishes (Nalge Nunc International, DK-4000 Roskilde, Denmark) at $38.5 \mathrm{C}$ in $5 \% \mathrm{CO}_{2}$ and $95 \%$ air. The following day, the BOEC culture was washed twice with PBS and incubated with culture medium supplemented with 5\% FCS. After monolayer formation, cells were trypsinized (0.05\% trypsin EDTA; Amresco, Solon, OH, USA) until single cells appeared, and these cells were again plated in 6-well culture dishes at a density of $3 \times 10^{4} / \mathrm{ml}$ and incubated at $38.5 \mathrm{C}$ in $5 \% \mathrm{CO}_{2}$ and $95 \%$ air in culture medium supplemented with 5\% FCS. The medium was renewed every $48 \mathrm{~h}$ until the growing BOEC monolayer covered $70-80 \%$ of the bottom of the culture plate. The purity of epithelial cell preparations was evaluated by reacting the cultured cells with monoclonal antibodies to cytokeratin (anti-cytokeratin-CK1) and immunostaining. The cells in the culture medium showed characteristic epithelial morphology. Approximately $98 \%$ of the cells were positive for anti-cytokeratin (CK1) antibodies.

\section{LPS and hormone treatments}

After the first passage but before the growing BOEC monolayer covered $70-80 \%$ of the bottom of the culture plate, in a preliminary study, the BOEC monolayer was washed twice with culture medium supplemented with $0.1 \% \mathrm{FCS}$ and incubated for $24 \mathrm{~h}$ with 4 doses (1, 10,100 and $1000 \mathrm{ng} / \mathrm{ml}$ ) of LPS (serotype E. coli 055:B5; Sigma). In this dose-response study, $1000 \mathrm{ng} / \mathrm{ml}$ of LPS had lethal effects on cell viability, and $1 \mathrm{ng} / \mathrm{ml}$ of LPS showed a lack of significant responses (Fig. 2). Therefore, for further experimentation, doses of 10 and $100 \mathrm{ng} / \mathrm{ml}$ of LPS were used. BOECs were stimulated with one of the following: (1) LPS (10 or $100 \mathrm{ng} / \mathrm{ml}$ ), (2) LPS (10 or 100 $\mathrm{ng} / \mathrm{ml})+\mathrm{LH}(10 \mathrm{ng} / \mathrm{ml}$, USDA-bLH-B6, USDA Animal Hormone Program, Bethesda, MD, USA), (3) LPS (10 or $100 \mathrm{ng} / \mathrm{ml})+$ P4 (1 $\mathrm{ng} / \mathrm{ml}$, Sigma) or (4) LPS (10 or $100 \mathrm{ng} / \mathrm{ml})+$ E2 (1 ng/ml, Sigma). As a control, culture medium without any LPS or hormones was added to the BOECs. The concentrations of hormones in this study were maintained similar to their physiological level in the bovine oviduct during the preovulatory period in situ [28]. This was done to mimic the local hormonal conditions around the time of ovulation in the oviduct when allogeneic sperm enters the oviduct and a semiallogeneic embryo is about to start to develop. Finally, the medium was collected, and cells in the plates were trypsinized, washed twice with $\mathrm{PBS}^{-/-}$and resuspended in $300 \mu \mathrm{PBS}^{-/-}$. A $10-\mu 1$ aliquot of the cell suspension was used to evaluate the cell viability. Cell viability was estimated using Trypan blue staining and was confirmed to be more than $90 \%$ at each time of plating as well as at the end of the experiment. The remaining cells were again separated by centrifugation at $300 \mathrm{~g}$ for $10 \mathrm{~min}$ at $4 \mathrm{C}$, lysed by TRIzol (Invitrogen, Carlsbad, USA) and stored at $-80 \mathrm{C}$ until RNA extraction.

\section{Extraction of RNA, production of $C D N A$ and real-time polymerase chain reaction (real-time $P C R$ )}

Total RNA was extracted from the BOECs using TRIzol (Invitrogen) as described in the protocol of Chomczynski and Sacchi [29]. The yield of extracted RNA for each sample was determined by ultraviolet (UV) spectroscopy (optical density, 260). The RNA concentration was measured using a spectrophotometer (Eppendorf, Munich, Germany) at absorbances of 260 and $280 \mathrm{~nm}$. The extracted total RNA was stored in RNA storage solution (Ambion, Austin, TX, USA) at -80 C until it was used for cDNA production. DNase treatment was carried out using an RQ1 RNase-Free DNase kit (Promega, Madison, WI, USA) as described previously [30]. The synthesized cDNA was stored at $-30 \mathrm{C}$. We analyzed the following genes: TLR $-4, T L R-2$, 
(A)
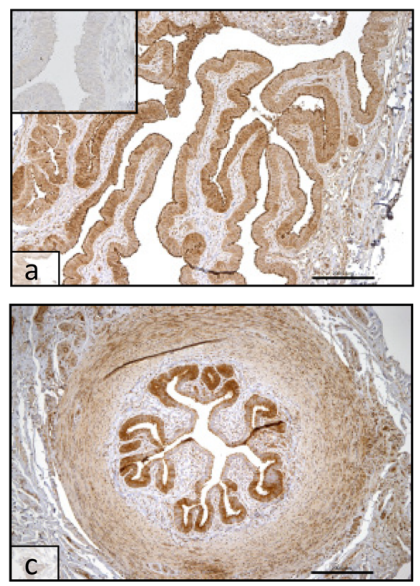

(B)
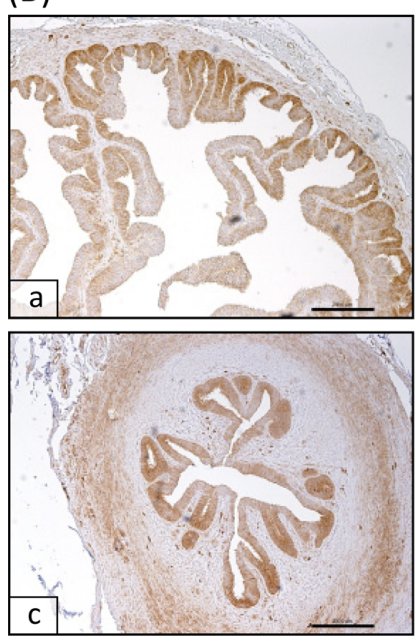
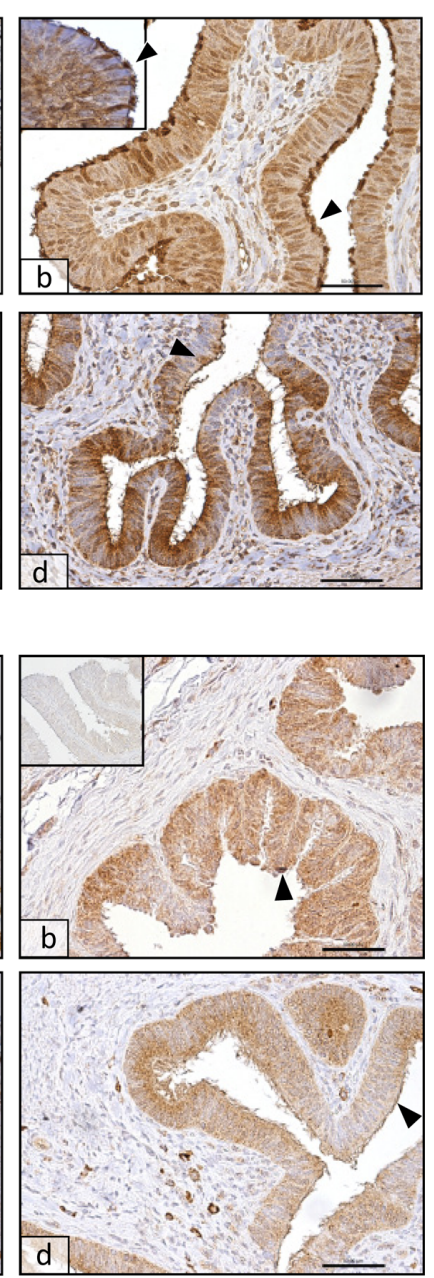

Fig. 1. (A) Immunohistochemical detection of TLR-2 in paraffin wax sections of the ampulla $(a, b)$ and isthmus $(c, d)$ of the bovine oviduct. The arrowhead (b, d) indicates the apical staining as well as staining of cells with apical cilia in the detailed picture in b. Insert in a: the control. Insert in b: detailed staining of cells with apical cilia. (B) Immunohistochemical detection of TLR-4 in paraffin wax sections of the ampulla $(a, b)$ and isthmus (c, d) of the bovine oviduct. The arrowhead indicates the apical staining in d. Insert in b: the control. Scale bars represent $50 \mu \mathrm{m}$.

COX-2, mPGES-1, TNF- $\alpha, I L 1-\beta, I L-10, I L-4, N F K B I A, C-F O S$ and $\beta$-actin (Table 1 lists primer sequences). Quantifications of mRNA expression were performed using synthesized cDNA via real-time PCR with a LightCycler (Roche Diagnostics, Mannheim, Germany) using a QuantiTect ${ }^{\mathrm{TM}}$ SYBR Green PCR Master Mix (QIAGEN, Hilden, Germany). The primers were designed using Primer3 based on bovine sequences. The amplification program consisted of 15 min of activation at $95 \mathrm{C}$, followed by 40 cycles of PCR ( $15 \mathrm{sec}$ of denaturation at $95 \mathrm{C}, 30 \mathrm{sec}$ of annealing at 54-58 C and $20 \mathrm{sec}$ of extension at $72 \mathrm{C}$ ). The values of mRNA expression were assayed by normalization to $\beta$-actin as the internal standard. The expression of $\beta$-actin was stable in all experiments, and no significant difference

was detected in the levels of $\beta$-actin expression between treatments.

\section{ELISA}

The prostaglandin E2 measurements in the medium were performed without further preparation of medium, using a second antibody enzyme immunoassay (EIA) according to a previous study [28]. Briefly, the assay was performed using 96-well ELISA plates (Corning, NY, USA) coated with $100 \mu \mathrm{g}$ of anti-rabbit IgG (Seikagaku, Tokyo, Japan). Basically, plates were incubated with $100 \mu$ polyclonal antibody solution $(1: 600,000)$ for $24 \mathrm{~h}$ at $4 \mathrm{C}$. The following day, plates were decanted, and $15 \mu \mathrm{l}$ of standards or samples were incubated with PGE2-HRP $(1: 40,000)$ for $24 \mathrm{~h}$ at $4 \mathrm{C}$.

\section{Immunohistochemistry}

The oviducts were transported from the local slaughterhouse to the laboratory while immersed in $0.9 \%$ saline solution in an ice box. The oviducts used in this study were from the preovulatory phase (days 19-20 of the cycle). The phase of the estrous cycle was identified as previously reported [28] based on the appearance of the corpus luteum, weight and color of the corpus luteum and follicular diameter. Paraffin-embedded tissue sections (4- $\mu \mathrm{m}$ thick) of the bovine ampulla or isthmus from the preovulatory phase were mounted on silane-treated glass slides (HistoBond Superior; Paul Marienfeld, Lauda-Königshofen, Germany) and dried at $37 \mathrm{C}$ for 24 h. After drying, they were deparaffinized in xylene and rehydrated in a series of solutions of graded alcohol concentrations. To block endogenous peroxidase activity, the sections were incubated for 30 min in $80 \%$ alcohol solution containing $2 \%$ hydrogen peroxide. After rinsing the sections three times for 5 min in PBS ( $\mathrm{pH} 7.2$ ), antigen retrieval was performed by boiling the sections in $10 \mathrm{mM}$ Tris Base and $1 \mathrm{mM}$ EDTA solution (pH 9) for $30 \mathrm{~min}$. The sections were then incubated for $20 \mathrm{~min}$ in $20 \%$ normal goat serum (in PBS) at room temperature to saturate any sites for nonspecific binding of proteins. The antibodies used for immunohistochemistry were rabbit anti-TLR-2 (1:100; orb11487, Biorbyt, Cambridge, UK) and rabbit anti-TLR-4 (1:200; 251111, Abbiotec, San Diego, CA, USA). The antibodies were diluted in PBS containing 1.5\% bovine serum albumin and incubated in a humidifier overnight at $4 \mathrm{C}$. For detection, an EnVision ${ }^{\mathrm{TM}}$ anti-rabbit immunoglobulin conjugated to peroxidase-labeled dextran polymer system (DAKO, Glostrup, Denmark) was used in accordance with the manufacturer's protocol. Finally, sections were washed with PBS, and peroxidase activity was detected using DAB (Sigma, Steinheim, Germany) as a substrate for $5 \mathrm{~min}$ at room temperature. Sections were counterstained with hemalum, dehydrated, and mounted with DPX (Fluka, Buchs, Switzerland). To analyze nonspecific binding, primary antibodies were replaced with rabbit $\operatorname{IgG}$ (Sigma) at the same concentration as that used for the primary antibody.

\section{Statistical analysis}

Data are presented as the mean \pm SEM. Statistical analyses were performed with StatView 5.0 (SAS Institute). One-way ANOVA followed by multiple comparison tests, Fisher (3 groups) and Bonferroni (more than 3 groups), was performed, and all results were considered to be statistically significant at $\mathrm{P}<0.05$. 

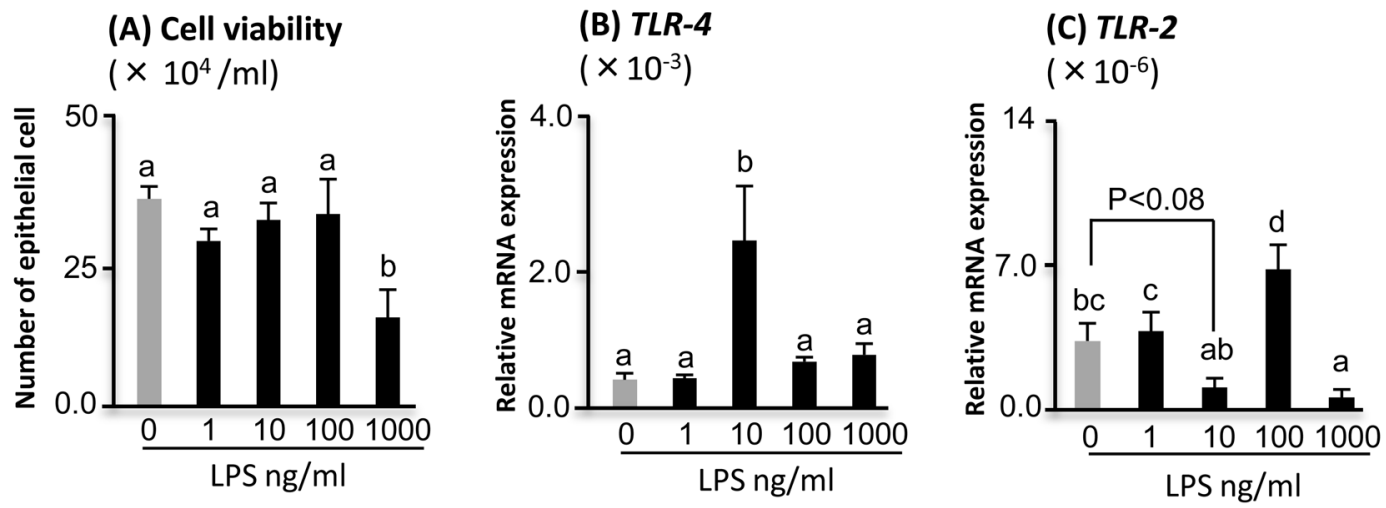

Fig. 2. Effect of O55:B5 E. coli lipopolysaccharide $(0,10,100$ and $1000 \mathrm{ng} / \mathrm{ml})$ on (A) cell viability estimated with the use of trypan blue, (B) relative mRNA expression of TLR-4 and (C) relative mRNA expression of TLR-2 in a dosedependent study in the bovine oviduct epithelial cell culture. Numerical values are presented as the mean \pm SEM of 5 experiments. Different letters indicate significant differences between the treatments at $\mathrm{P}<0.05$ as determined by ANOVA followed by Bonferroni's multiple comparison test.

Table 1. Bovine primers were used in real-time PCR

\begin{tabular}{|c|c|c|c|c|c|}
\hline Gene & & Sequence of nucleotide $\left(5^{\prime}-3^{\prime}\right) *$ & Accession No. & $\operatorname{Tm}(\mathrm{C})$ & Product size (bp) \\
\hline \multirow[t]{2}{*}{$T L R-4$} & $\mathrm{~F}$ & CTTGCGTACAGGTTGTTCCTAA & NM_174198.6 & 56 & 153 \\
\hline & $\mathrm{R}$ & CTGGGAAGCTGGAGAAGTTATG & & & \\
\hline \multirow[t]{2}{*}{$T L R-2$} & $\mathrm{~F}$ & GCTCCTGTGACTTCCTGTCC & NM_174197.2 & 54 & 501 \\
\hline & $\mathrm{R}$ & CCGAAAGCACAAAGATGGTT & & & \\
\hline \multirow[t]{2}{*}{ NFKBIA } & $\mathrm{F}$ & AAGTGGTCCGCCAAGTGAAG & NM_001045868.1 & 58 & 105 \\
\hline & $\mathrm{R}$ & CGATTTCTGGCTGGTTAGTGATC & & & \\
\hline \multirow[t]{2}{*}{$C-F O S$} & $\mathrm{~F}$ & GAACGGAATAAGATGGCTGC & NM_001001162.1 & 58 & 220 \\
\hline & $\mathrm{R}$ & CCACAGACATCTCCTCTGGG & & & \\
\hline \multirow{2}{*}{$C O X-2$} & $\mathrm{~F}$ & TCCTGAAACCCACTCCCAACA & AF031698 & 54 & 241 \\
\hline & $\mathrm{R}$ & TGGGCAGTCATCAGGCACAG & & & \\
\hline \multirow[t]{2}{*}{$m P G E S-1$} & $\mathrm{~F}$ & AGGACGCTCAGAGACATGGA & NM174443 & 58 & 142 \\
\hline & $\mathrm{R}$ & TTCGGTCCGAGGAAAGAGTA & & & \\
\hline \multirow[t]{2}{*}{$I L-1 \beta$} & $\mathrm{F}$ & ATGAAGAGCTGCATCCAACA & NM_174093.1 & 56 & 196 \\
\hline & $\mathrm{R}$ & ATGGAAGACATGTGCGTAGG & & & \\
\hline \multirow[t]{2}{*}{$I L-4$} & $\mathrm{~F}$ & GCCACACGTGCTTGAACAAA & NM_173921.2 & 56 & 63 \\
\hline & $\mathrm{R}$ & TGCTTGCCAAGCTGTTGAGA & & & \\
\hline \multirow[t]{2}{*}{$I L-10$} & $\mathrm{~F}$ & TTCTGCCCTGCGAAAACAA & NM_174088.1 & 58 & 85 \\
\hline & $\mathrm{R}$ & TCTCTTGGAGCTCACTGAAGACTCT & & & \\
\hline \multirow[t]{2}{*}{$T N F-\alpha$} & $\mathrm{F}$ & TGACGGGCTTTACCTCATCT & NM_173966.3 & 56 & 221 \\
\hline & $\mathrm{R}$ & TGATGGCAGACAGGATGTTG & & & \\
\hline \multirow[t]{2}{*}{$\beta$-actin } & $\mathrm{F}$ & CCAAGGCCAACCGTGAGAAAAT & K00622 & 58 & 256 \\
\hline & $\mathrm{R}$ & CCACATTCCGTGAGGATCTTCA & & & \\
\hline
\end{tabular}

* F, forward; $\mathrm{R}$, reverse.

\section{Results}

The bovine oviduct expresses proteins for TLR-4 and TLR-2

We investigated the expression of TLR-4 and TLR-2 in the bovine oviduct because it is hypothesized that the oviduct controls immune responses through variation in TLR signaling, which in turn, results in the production of different cytokines and chemokines. Figure 1 shows, by means of immunohistochemistry and intensive staining of epithelial cells, the expression of TLR-4 and TLR-2 in the bovine oviduct.

Dose-dependent stimulation of BOECs by LPS results in different expressions of TLR-4 and TLR-2

A dose-response study was performed, in which epithelial cells were incubated in $0.1 \%$ FCS medium alone or in increasing doses of LPS $(1,10,100$ and $1000 \mathrm{ng} / \mathrm{ml})$ for $24 \mathrm{~h}$. LPS at a dose of 
$1000 \mathrm{ng} / \mathrm{ml}$ was toxic and significantly reduced the cell viability of BOECs (Fig. 2A, $\mathrm{P}<0.05$ ). The results also showed that BOECs are sensitive to LPS. Elevated expression of TLR-4 indicated earlyimmune responses after administration of a low dose of LPS (10 ng/ $\mathrm{ml}$ ) (Fig. 2B, $\mathrm{P}<0.05)$. Higher doses of LPS (100 and $1000 \mathrm{ng} / \mathrm{ml}$ ) did not induce TLR-4 expression. However, administration of 100 ng/ml LPS upregulated TLR-2 expression while $1000 \mathrm{ng} / \mathrm{ml}$ LPS downregulated $T L R-2$ expression (Fig. $2 \mathrm{C}, \mathrm{P}<0.05$ ).

\section{Immunological responses of BOECs to the different doses of LPS}

Stimulation of BOECs with $10 \mathrm{ng} / \mathrm{ml}$ LPS significantly increased the expression of TLR-4, NFKBIA, COX-2,IL1- $\beta$ and TNF- $\alpha$ (Fig. $3 \mathrm{~A}-\mathrm{E}, \mathrm{P}<0.05)$. However, $100 \mathrm{ng} / \mathrm{ml}$ LPS did not induce the expression of TLR-4, NFKBIA, COX-2,IL1- $\beta$ and TNF- $\alpha$ but increased the expression of $T L R-2, I L-10$ and $I L-4$ (Fig. $3 F, H$ and I, $\mathrm{P}<0.05$ ).

\section{Ovarian steroids and LH completely block LPS-induced responses in the $B O E C$}

The effect of ovarian steroids, E2 and P4, and LH on the proinflammatory response of the BOEC to LPS was investigated because the oviduct microenvironment is constantly exposed to sex hormones during the estrous cycle. BOECs were stimulated with LH (10 ng/ $\mathrm{ml}) \mathrm{P} 4(1 \mathrm{ng} / \mathrm{ml})$ and E2 (1 ng/ml) at concentrations observed during the preovulatory period in situ. Ovarian steroids and LH completely suppressed LPS (10 ng/ml)-induced expression of TLR-4, IL-1 $\beta$ and $T N F-\alpha$ (Fig. 4A, C and D, $\mathrm{P}<0.05$ ). Stimulation of BOECs with 10 $\mathrm{ng} / \mathrm{ml}$ of LPS together with either P4 or LH also suppressed the stimulatory effect of LPS $(10 \mathrm{ng} / \mathrm{ml})$ on $C O X-2$ expression (Fig. $4 \mathrm{E}, \mathrm{P}<0.05)$. Stimulation of the cells by $10 \mathrm{ng} / \mathrm{ml} \mathrm{LPS}$ together with either P4 or E2 reduced LPS (10 $\mathrm{ng} / \mathrm{ml})$-induced NFKBIA expression (Fig. 4B, $\mathrm{P}<0.05$ ). Ovarian steroids and $\mathrm{LH}$ also inhibited the stimulatory effect of $100 \mathrm{ng} / \mathrm{ml}$ LPS on TLR-2 expression (Fig. 4F, $\mathrm{P}<0.05)$. Moreover, E2 inhibited stimulatory effects of $100 \mathrm{ng} / \mathrm{ml}$ LPS on $I L-10$ expression (Fig. $4 \mathrm{H}, \mathrm{P}<0.05$ ). Stimulation of BOECs with $100 \mathrm{ng} / \mathrm{ml}$ LPS together with E2 induced C-FOS expression compared with LPS (100 ng/ml)-stimulated cells (Fig. 4G, P<0.05).

\section{Regulation of prostaglandin E2 secretion by LPS, E2 and LH in the BOEC}

A dose of $100 \mathrm{ng} / \mathrm{ml}$ of LPS significantly stimulated $\mathrm{mPGES}-1$ expression and PGE2 secretion in BOEC culture (Fig. 5A-B, $\mathrm{P}<0.05$ ).

\section{Discussion}

The results of this study provide evidence that the bovine oviduct expresses genes and proteins for both TLR-4 and TLR-2. Intensive expression of these TLRs was found within the epithelial cells. Interestingly, TLR-2 and TLR-4 were highly expressed in the apical cilia rather than basolateral pole of the bovine oviduct epithelial cells. This suggests higher sensitivity of the oviduct epithelial cells to the possible TLRs ligands in the oviduct fluid. Previous studies showed that TLR-2, but not TLR-4, is expressed in the murine oviduct [31]. The human oviduct has been shown to express TLR-2, and TLR-4 is expressed within oviductal stromal fibroblasts but not oviductal epithelial cells $[32,33]$. These findings indicate the existence of a species-specific difference in oviduct mucosal immunity.

In this study, $10 \mathrm{ng} / \mathrm{ml}$ LPS induced expression of TLR-4 but not $T L R-2$, and a 10-fold higher concentration of LPS increased the expression of $T L R-2$ but not TLR-4. Hearth et al. [34] reported that $1000 \mathrm{ng} / \mathrm{ml}$ E. coli LPS induced TLR-4 expression in the endometrial cells of the bovine uterus, and Ibeagha-Awemu et al. [15] found that $0.01-10 \mu \mathrm{g} / \mathrm{ml}$ LPS stimulates the expression of both TLR-4 and $T L R-2$ in bovine mammary epithelial cells. The absence of an effect of LPS at the dose of $100 \mathrm{ng} / \mathrm{ml}$ on the expression of TLR-4 could be due to the concomitant upregulation of Th2 cytokines such as $I L-4$. It has been shown that IL-4 reduces LPS responsiveness and TLR-4 protein surface expression, TLR-4 mRNA expression and transcriptional activity of the upstream region of TLR- 4 in intestinal epithelial cells and PBMCs $[35,36]$. This effect is dependent on tyrosine kinase and STAT6. A STAT6 binding site has been determined in an area of the TLR-4 gene necessary to mediate the inhibitory effects of IL-4 on TLR-4 transcription [36]. The present data may imply a novel autonomous innate immunity in the bovine oviduct.

Exposure of epithelial cells to $10 \mathrm{ng} / \mathrm{ml}$ LPS induced the expression of $T L R-4, C O X-2$, and Th1 cytokines (i.e., $I L-1 \beta$ and $T N F-\alpha$ ), demonstrating a high sensitivity of oviduct epithelial cells to low-dose LPS. Interleukin- $1 \beta$ and TNF- $\alpha$ are known to be involved in the inflammatory responses of the human oviduct to Chlamydia trachomatis infection $[37,38]$. The induction of $C O X-2$, an important downstream target of TLR-4 signaling [39], increases epithelial production of PGE2 and causes proliferation in infected epithelial cells [40]. The present results imply that the bovine oviduct epithelial cell may employ an early and sensitive innate surveillance (manifested by elevated TLR-4 expression) to preclude infection. This could be sufficient to provide a sterile microenvironment and, at the same time, protection from infection.

Interestingly, low-dose LPS also stimulated the expression of $N F K B I A$, which is NF- $\kappa \mathrm{B}$-dependent. NFKBIA strongly sequesters $\mathrm{NF}-\kappa \mathrm{B}$ in the cytoplasm, thereby generating autoregulatory feedback loops in the NF- $\kappa B$ response [41]. Rodrigues et al. [42] found increased NFKBIA expression in the rat epididymis challenged by $E$. coli LPS after $2 \mathrm{~h}$ of exposure in vivo. Thus, in the present study, a low dose of LPS induced NFKBIA expression, possibly providing a compensatory mechanism to balance activation of NF- $\mathrm{KB}$.

Importantly, $100 \mathrm{ng} / \mathrm{ml}$ LPS did not induce TLR -4 and Th1 cytokines but stimulated the expression of $T L R-2$ and Th2 cytokines (i.e., $I L-4$ and $I L-10)$. We propose two possibilities to explain this phenomenon (Fig. 6). First, the high levels of IL-1 $\beta$ and TNF- $\alpha$ during infection are clearly detrimental to the human oviduct $[37,38]$, leading to barrier disruption, subsequent translocation of bacteria to the lamina propria [43] and disturbance of the natural tolerance mediated by regulatory T cells and immunosuppressive cytokines [44]. Because of this, it is hypothesized that the BOEC responds to $100 \mathrm{ng} / \mathrm{ml} \mathrm{LPS}$ through suppression of TLR-4 and Th1 cytokines to prevent severe tubal injury. Moreover, TLR-2 critically participates in protection of the intestinal epithelial barrier and controls mucosal inflammation by directly preserving tight junctions [11]. Thus, upregulation of TLR-2 by $100 \mathrm{ng} / \mathrm{ml}$ LPS may also involve in preserving oviductal epithelial barrier. In addition, according to the theory of Th2-mediated repair, many of the proteins produced in response to IL-4 are associated with injury and have well-known roles in tissue repair [45]. 
(A) TLR-4

$\left(\times 10^{-3}\right)$

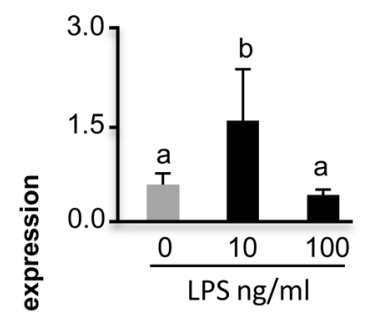

(F) $T L R-2$

$\left(\times 10^{-4}\right)$

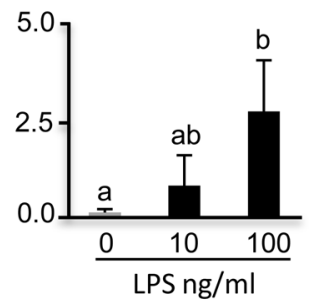

(B) NFKBIA

$\left(\times 10^{-2}\right)$

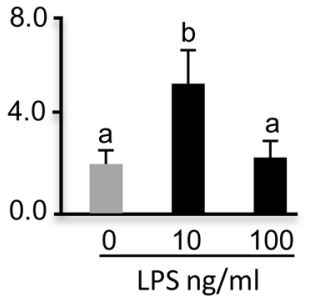

(G) C-FOS

$\left(\times 10^{-4}\right)$

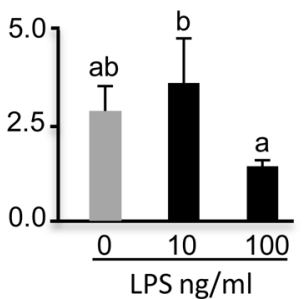

(C) IL-1 $\beta$

$\left(\times 10^{-3}\right)$

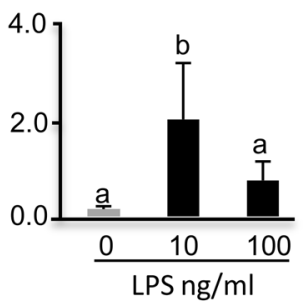

(H) IL-10

$\left(\times 10^{-4}\right)$

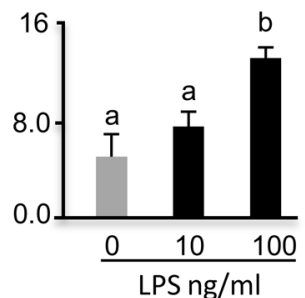

(D) $T N F-\alpha$

$\left(\times 10^{-2}\right)$

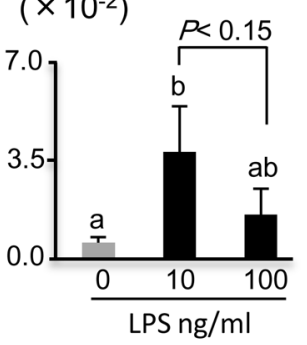

(I) IL-4

$\left(\times 10^{-5}\right)$

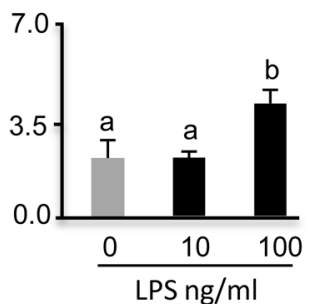

Fig. 3. Relative mRNA expression of $T L R-4, C O X-2, I L-1 \beta, T N F-a, T L R-2, C-F O S, I L-10, I L-4$ and $N F K B I A$ in the bovine oviduct epithelial cell culture stimulated with different doses of O55:B5 E. coli lipopolysaccharide (10 and $100 \mathrm{ng} / \mathrm{ml})$ and harvested after $24 \mathrm{~h}$. Numerical values are presented as the mean \pm SEM of 5 experiments. Different letters indicate significant differences between the treatments at $\mathrm{P}<0.05$ as determined by ANOVA followed by Fisher's multiple comparison test.

(A) TLR-4

$\left(\times 10^{-3}\right)$

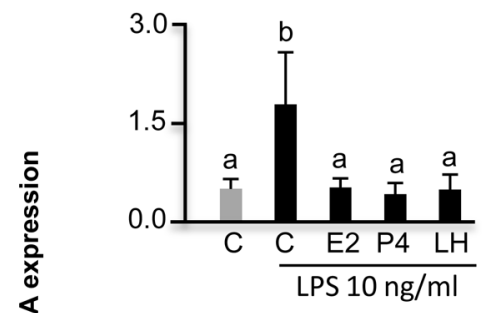

(E) COX-2

$\left(\times 10^{-3}\right)$

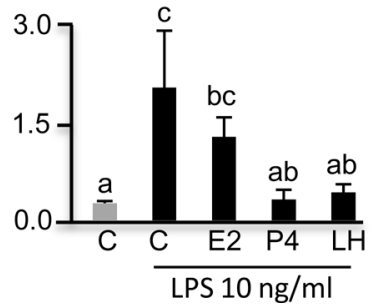

(B) NFKBIA

$\left(\times 10^{-2}\right)$

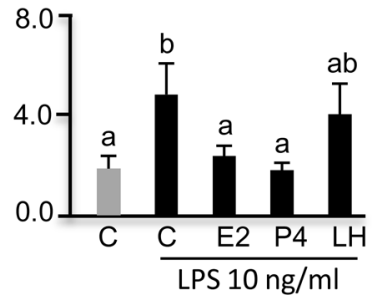

(F) TLR-2

$\left(\times 10^{-5}\right)$

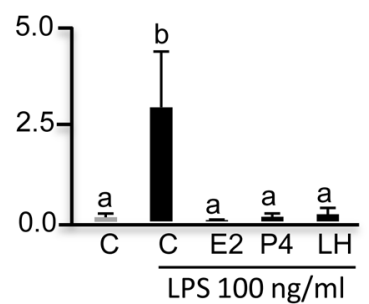

(C) IL-1 $\beta$

$\left(\times 10^{-3}\right)$

(D) TNF-a

$\left(\times 10^{-2}\right)$
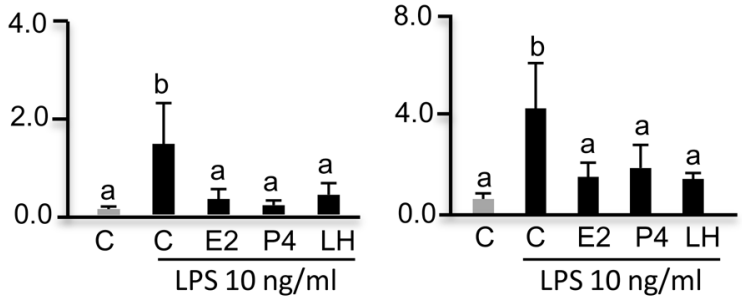

(G) C-FOS

$\left(\times 10^{-2}\right)$

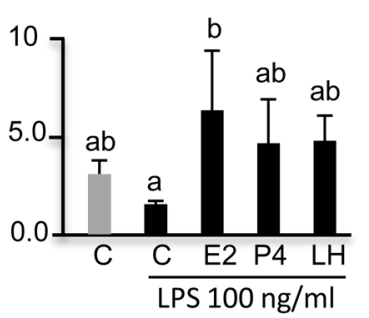

(E) COX-2

$\left(\times 10^{-3}\right)$

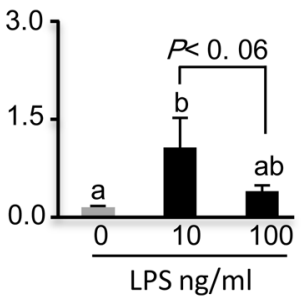


(A) MPGES-1 $\left(\times 10^{-5}\right)$
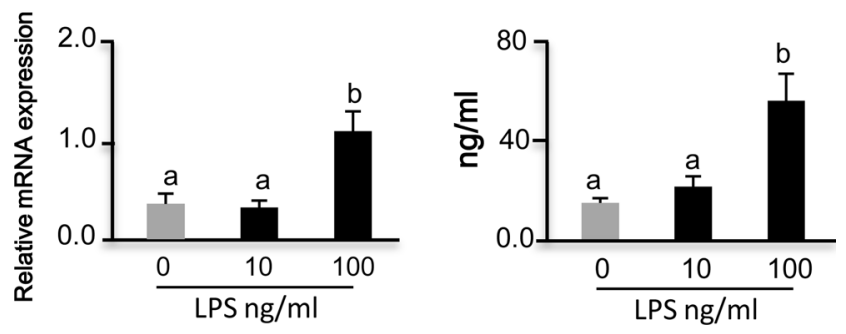

Fig. 5. Effect of different doses of O55:B5 E. coli lipopolysaccharide ( 0 , 10 and $100 \mathrm{ng} / \mathrm{ml}$ ) on (A) mRNA expression of $\mathrm{m} P G E S-1$ and (B) PGE2 secretion in the bovine oviduct epithelial cell culture. C (gray bar): control without any stimulant. Numerical values are presented as the mean \pm SEM of 5 experiments. Different letters indicate significant differences between the treatments at $\mathrm{P}<0.05$ as determined by ANOVA followed by Fisher's multiple comparison test.

Second, although TLRs are crucial for an efficient immune response, certain pathogens use TLR-based strategies to evade the host defense, preventing further elimination of the microorganisms [9]. TLR-2, which is a strong mediator of anti-inflammatory effects [9], and TLR-4 are involved in $I L-10$ expression [46]. E. coli LPS induces $T L R-2$ expression and sensitivity of TLR-2 to stimulations [12-14]. LPS is known to signal through TLR-2 [47]. E. coli LPS in vitro activates spleen cells from TLR-2 $2^{+/+}$mice to induce production of the Th2-polarizing cytokine IL-10 [48]. Moreover, in the presence of myeloid differentiation protein 2 (MD-2, a protein associated with TLR-4 on the cell surface and needed for TLR-4 to respond to LPS), both TLR-2 and TLR-4 are highly and equally sensitive to all endotoxic LPS, including protein-free LPS [49]. MD-2 enhances TLR2-mediated responsiveness to both gram-negative and gram-positive bacteria [49]. The present results suggest that a dose of $100 \mathrm{ng} / \mathrm{ml}$ of LPS increases the expression of TLR-2, which is accompanied by elevated expression of Th2 cytokines, and the concomitant decrease in the expressions of TLR-4 and Th1 cytokines. It is proposed that this arrangement is related to mucosal homeostasis via mucosal barrier protection and the prevention of expanding inflammation. It may also serve as a mechanism of escape from the oviduct defense for gram-negative bacteria.

A dose of $100 \mathrm{ng} / \mathrm{ml}$ LPS stimulated the expression of $\mathrm{mPGES}-1$ and PGE2 secretion but not $C O X-2$ expression. It is documented that both TLR-4 and TLR-2 are involved in PGE2 secretion [50, 51]. LPS stimulates PGE2 production in bovine endometrial cells [34]. TLR-2 is also the major receptor that mediates PGE2 production in response to $C$. albicans in murine peritoneal macrophages and splenocytes [51]. The present results suggest that elevated expression of $T L R-2$ in cells treated with $100 \mathrm{ng} / \mathrm{ml}$ could induce $\mathrm{m} P G E S-1$ expression and PGE2 secretion. Interestingly, despite the well-known regulatory coupling of the two enzymes, COX-2 and mPGES-1, LPS at a dose of $10 \mathrm{ng} / \mathrm{ml}$ induced $C O X-2$ expression but not $\mathrm{m} P G E S-1$ expression and resultant PGE2 secretion. Arosh et al. [52] also reported that $\mathrm{m} P G E S-1$ expression is not coupled to the expression of COX-2 in

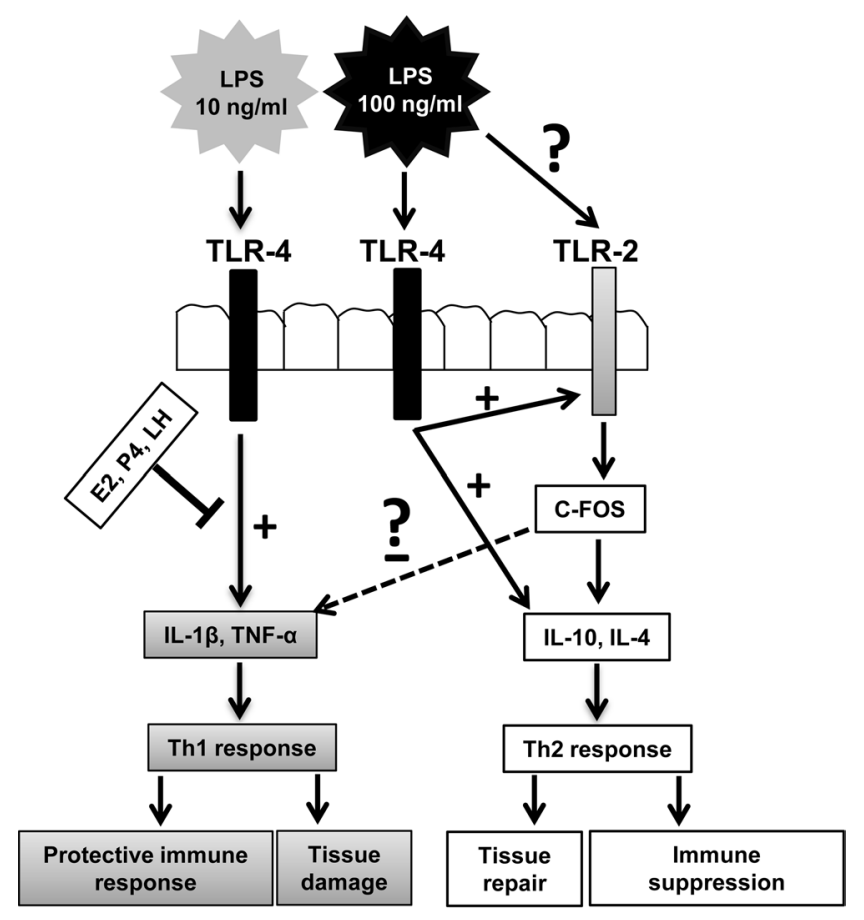

Fig. 6. Schematic illustration for a novel regulation of local innate immunity in the bovine oviduct. Differential TLR-mediated pathways can induce specificity to innate immunity. Recent literature suggests that certain microorganisms not only are recognized by TLRs for the activation of host defense but also activate alternative TLR pathways with inhibitory effects on innate immunity. Interaction of $10 \mathrm{ng} / \mathrm{ml} \mathrm{E}$. coli LPS with TLR4 induces expression of Th1 cytokines, which switches to a protective immune response, while activation of TLR-4, together with possible TLR-2 signaling by $100 \mathrm{ng} / \mathrm{ml}$ E. coli LPS, induces the expression of Th2 cytokines, which switches to an immune suppression. This results in inhibition of host defense and increased susceptibility to infection. Similar mechanisms have been suggested for other microorganisms, such as $Y$. enterocolitica and A. fumigates [20]. On the other hand, Th2 cytokines and TLR-2 play important roles in preserving tight junctions and tissue repair. Moreover, ovarian steroids and $\mathrm{LH}$ markedly influence innate immune protection by epithelial cells in the oviduct through inhibition of pro-inflammatory responses.

the endometrium stimulated with interferon-tau. It seems that the expression of $C O X-2$ and $\mathrm{mPGES}-1$ in response to LPS may also be uncoupled in the BOEC. Therefore, PGE2 secretion could be controlled by mPGES-1 but not COX-2 in BOEC culture in response to LPS.

An important finding of our study is that E2, P4 and LH, at the concentrations observed around ovulation in situ, completely reversed the stimulatory effect of $10 \mathrm{ng} / \mathrm{ml}$ LPS on TLR-4 expression and TLR4-related genes. Moreover, E2, P4 and LH suppressed TLR-2 expression in response to $100 \mathrm{ng} / \mathrm{ml} \mathrm{LPS}$, and E2 reversed LPS induction of $I L-10$ expression. Fahey et al. [53] reported that $\mathrm{E} 2$ can reverse the stimulatory effects of IL- $1 \beta$ on the expression of $T N F-a$, $I L-8$ and $N F-\kappa B$ in human uterine epithelial cells. It has been shown that the inhibitory effects of E2 and P4 on LPS-induced immune responses are receptor mediated in human uterine epithelial cells and murine bone marrow stem cells [53, 54]. Since the bovine oviduct and 
BOEC express receptors for LH [22], E2 and P4 [23], the inhibition of LPS-induced TLR-4 and TLR-4 related genes by these hormones may be mediated through receptors in the BOEC. The present data imply that the periovulatory levels of E2, P4 and LH accomplish downregulation of both Th1 and Th2 responses during infection to prevent harmful changes in the oviduct microenvironment, particularly when allogeneic sperm enters the oviduct and a semi-allogeneic embryo is about to start to develop. However, this may lead to loss of immune responses, resulting in tissue damage by bacteria or toxins. It has been reported that despite suppression of LPS-induced NF- $\kappa B$ and proinflammatory responses by E2 in human uterine epithelial cells, E2 induces antimicrobial protein secretory leukocyte protease inhibitor (SLPI) [53]. Therefore, on the one hand, these hormones may enhance protection against pathogens by increasing antimicrobial activity. On the other, they may ensure an environment for successful fertilization by suppressing proinflammatory responses detrimental to allogeneic sperm and a semi-allogeneic embryo. However, if the invasion of infection overwhelms the immune capacity, the affected cells or tissue appear to be endangered by bacteria or toxins.

Taken together, these findings shed a light on a novel immune function of the BOEC, which initiates a biphasic and sensitive proinflammatory response to infection. A low dose of E. coli LPS initiate a Th1-type response, but at a higher LPS dose, the immune response switches to a Th2-type response. In addition, ovarian steroids and LH suppress LPS-induced pro-inflammatory responses. Therefore, epithelial cells employ ovarian steroids and LH in maintaining microenvironmental homeostasis of the oviduct, guaranteeing an optimal microenvironment to achieve successful fertilization via inhibition of Th1 responses detrimental to allogeneic sperm and the semi-allogeneic embryo in the bovine oviduct. Since the responses to LPS and hormones could be modulated by other cells and factors as well as epithelial cells in the oviduct, further investigation will focus on the possible interactions among epithelial cells, immune cells and other cell types.

\section{References}

1. Kölle S, Reese S, Kummer W. New aspects of gamete transport, fertilization, and embryonic development in the oviduct gained by means of live cell imaging. Theriogenology 2010; 73: 786-795. [Medline]

2. Herath S, Williams EJ, Lilly ST, Gilbert RO, Dobson H, Bryant CE, Sheldon IM. Ovarian follicular cells have innate immune capabilities that modulate their endocrine function. Reproduction 2007; 134: 683-693. [Medline]

3. Swamy M, Jamora C, Havran W, Hayday A. Epithelial decision makers: In search of the 'epimmunome'. Nat Immunol 2010; 11: 656-665. [Medline]

4. Schleimer RP, Kato A, Kern R, Kuperman D, Avila PC. Epithelium: At the interface of innate and adaptive immune responses. J Allergy Clin Immunol 2007; 120: 1279-1284. [Medline]

5. Bulek K, Swaidani S, Aronica M, Li X. Epithelium: The interplay between innate and Th2 immunity. Immunol Cell Biol 2010; 88: 257-268. [Medline]

6. Kumar H, Kawai T, Akira S. Toll-like receptors and innate immunity. Biochem Biophys Res Commun 2009; 388: 621-625. [Medline]

7. Medzhitov R, Preston-Hurlburt P, Janeway CA Jr. A human homologue of the Drosophila Toll protein signals activation of adaptive immunity. Nature 1997; 388: 394-397. [Medline]

8. McGuire K, Jones M, Werling D, Williams JL, Glass EJ, Jann O. Radiation hybrid mapping of all 10 characterized bovine Toll-like receptors. Anim Genet 2006; 37: 47-50. [Medline]

9. Netea MG, Van der Meer Jos VM, Kullberg B. Toll-like receptors as an escape mechanism from the host defense. Trends Microbiol 2004; 12: 484-488. [Medline]

10. O'Neill LAG. How Toll-like receptors signal: What we know and what we don't know.
Curr Opin Immunol 2006; 18: 3-9. [Medline]

11. Cario E. Barrier-protective function of intestinal epithelial Toll-like receptor 2. Mucosal Immunology 2008; 1: S62-S66. [Medline]

12. Spiller S, Elson G, Ferstl R, Dreher S, Mueller T, Freudenberg M, Daubeuf B, Wagner H, Kirschning CJ. TLR4-induced IFN $\gamma$ production increases TLR2 sensitivity and drives gram-negative sepsis in mice. $J$ Exp Med 2008; 205: 1747-1754. [Medline]

13. Maris NA, Dessing MC, deVos AF, Bresser P, Van der Zee JS, Jansen HM, Spek CA, Van der Poll T. Toll-like receptor mRNA levels in alveolar macrophages after inhalation of endotoxin. Eur Respir J 2006; 28: 622-626. [Medline]

14. Liu Y, Wang Y, Yamakuchi M, Isowaki S, Nagata E, Kanmura Y, Kitajima I, Maruyama I. Upregulation of Toll-like receptor 2 gene expression in macrophage response to peptidoglycan and high concentration of lipopolysaccharide is involved in NF-kB activation. Infect Immun 2001; 69: 2788-2796. [Medline]

15. Ibeagha-Awemu EM, Lee JW, Ibeagha AE, Bannerman DD, Paape MJ, Zhao X. Bacterial lipopolysaccharide induces increased expression of toll-like receptor (TLR) 4 and downstream TLR signaling molecules in bovine mammary epithelial cells. Vet Res 2008; 39: 11. [Medline]

16. Fan J, Frey RS, Malik AB. TLR4 signaling induces TLR 2 expression in endothelial cells via neutrophil NADPH oxidase. J Clin Invest 2003; 112: 1234-1243. [Medline]

17. Faure E, Thomas L, Xu H, Medvedev AE, Equils O, Arditi M. Bacterial lipopolysaccharide and IFN $\gamma$ induce Toll-like receptor 2 and Toll-like receptor 4 expression in human endothelial cells: Role of NF-kB activation. J Immunol 2001; 166: 2018-2024. [Medline]

18. Kirschning CJ, Wesche H, Ayres TM, Rothe M. Human Toll-like receptor 2 confers responsiveness to bacterial lipopolysaccharide. J Exp Med 1998; 188: 2091-2097. [Medline]

19. Yang RB, Mark MR, Gray A, Huang A, Xie MH, Zhang M, Goddard A, Wood WI, Gurney AL, Godowski PJ. Toll-like receptor-2 mediates lipopolysaccharide-induced cellular signaling. Nature 1998; 395: 284-288. [Medline]

20. Netea MG, Van der Meer Jos VM, Sutmuller RP, Adema GJ, Kullberg B. From the Th1/Th2 paradigm towards a Toll-like receptor/T-helper bias. Antimicrob Agents Chemother 2005; 49: 3991-3996. [Medline]

21. Verthelyi D. Sex hormones as immunomodulators in health and disease. Int Immunopharmacol 2001; 1: 983-993. [Medline]

22. Sun T, Lei ZM, Rao CV. A novel regulation of the oviductal glycoprotein gene expression by luteinizing hormone in bovine tubal epithelial cells. Mol Cell Endocrinol 1997; 131 97-108. [Medline]

23. Ulbrich SE, Kettler A, Einspanier R. Expression and localization of estrogen receptor $\alpha$, estrogen receptor $\beta$ and progesterone receptor in the bovine oviduct in vivo and in vitro. $J$ Steroid Biochem Mol Biol 2003; 84: 279-289. [Medline]

24. Giannoni E, Guignard L, Reymond MK, Perreau M, Roth-Kleiner M, Calandra T, Roger T. Estradiol and progesterone strongly inhibit the innate immune response of mononuclear cells in newborns. Infect Immun 2011; 79: 2690-2698. [Medline]

25. Critchley HOD, Kelly RW, Brenner RM, Baird DT. The endocrinology of menstruation - a role for the immune system. Clin Endocrinol (Oxf) 2001; 55: 701-710. [Medline]

26. Way AL. Isolation and culture of bovine oviductal epithelial cells for use in the anatomy and physiology laboratory and undergraduate research. Adv Physiol Educ 2006; 30 237-241. [Medline]

27. Wijayagunawardane MPB, Kodithuwakku SP, Yamamoto D, Miyamoto A. Vascular endothelial growth factor system in the cow oviduct: A possible involvement in the regulation of oviductal motility and embryo transport. Mol Reprod Dev 2005; 72: 511-520. [Medline]

28. Wijayagunawardane MPB, Miyamoto A, Cerbito WA, Acosta TJ, Takagi M, Sato K. Local distributions of oviductal estradiol, progesterone, prostaglandins, oxytocin and endothelin in the cyclic cow. Theriogenology 1998; 49: 607-618. [Medline]

29. Chomezynski P, Sacchi N. Single-step method of RNA isolation by acid guanidinium thiocyanate-phenol-chloroform extraction. Anal Biochem 1987; 162: 156-159. [Medline]

30. Watanabe S, Shirasuna K, Matsui M, Yamamoto D, Berisha B, Schams D, Miyamoto A. Effect of intraluteal injection of endothelin type A receptor antagonist on PGF2 alphainduced luteolysis in the cow. J Reprod Dev 2006; 52: 551-559. [Medline]

31. Derbigny WA, Kerr MS, Johnson RM. Pattern recognition molecules activated by Chlamydia muridarum infection of cloned murine oviduct epithelial cell lines. J Immunol 2005; 175: 6065-6075. [Medline]

32. Itoh H, Nasu K, Nishida M, Matsumoto H, Yuge A, Narahara H. Human oviductal stromal fibroblasts, but not oviductal epithelial cells, express Toll-like receptor 4: The site-specific mucosal immunity of the human fallopian tube against bacterial infection. $\mathrm{Am}$ J Reprod Immunol 2006; 56: 91-101. [Medline]

33. Pioli PA, Amiel E, Schaefer TM, Connolly JE, Wira CR, Guyre PM. Differential expression of Toll-like receptors 2 and 4 in tissues of the human female reproductive tract. Infect Immun 2004; 72: 5799-5806. [Medline]

34. Herath S, Fischer DP, Werling D, Williams EJ, Lilly ST, Dobson H, Bryant CE, Sheldon IM. Expression and function of Toll-like receptor 4 in the endometrial cells of the uterus. Endocrinology 2006; 147: 562-570. [Medline]

35. Mueller T, Terada T, Rosenberg IM, Shibolet O, Podolsky DK. Th2 cytokines down- 
regulate TLR expression and function in human intestinal epithelial cells. J Immunol 2006; 176: 5805-5814. [Medline]

36. Fiset PO, Tulic MK, Skrablin PSA, Grover SM, Letuve S, Mazer BD, Hamid Q. Signal transducer and activator of transcription 6 downregulates toll-like receptor-4 expression of a monocytic cell line. Clin Exp Allergy 2006; 36: 158-165. [Medline]

37. Ault KA, Tawfik OW, Smith-King MM, Gunter J, Terranova PF. Tumor necrosis factor $\alpha$ response to infection with trachomatis in human fallopian tube organ culture. Am J Obstet Gynecol 1996; 175: 1242-1245. [Medline]

38. Hvid M, Baczynska A, Deleuran B, Fedder J, Knudsen HJ, Christiansen G, Birkelund S. Interleukin-1 is the initiator of fallopian tube destruction during Chlamydia Trachomatis infection. Cell Microbiol 2007; 9: 2795-2803. [Medline]

39. Rhee SH, Hwang D. Murine Toll-like receptor 4 confers lipopolysaccharide responsiveness as determined by activation of NF-kB and expression of the inducible cyclooxygenase. J Biol Chem 2000; 275: 34035-34040. [Medline]

40. Fukata M, Chen A, Klepper A, Krishnareddy S, Vamadevan AS, Thomas LS, Xu R, Inoue H, Arditi M, Dannenberg AJ, Abreu MT. COX2 is regulated by Toll-like receptor4 (TLR4) signaling and is important for proliferation and apoptosis in response to intestinal mucosal injury. Gastroenterology 2006; 131: 862-877. [Medline]

41. Oeckinghaus A, Ghosh S. The NF-kB family of transcription factors and its regulation. Cold Spring Harb Perspect Biol 2009; 1: a000034. [Medline]

42. Rodrigues A, Queiróz DBC, Honda L, Silva EJR, Hall SH, Avellar MCW. Activation of Toll-like receptor 4 (TLR4) by in vivo and in vitro exposure of rat epididymis to lipopolysaccharide from Escherichia Coli. Biol Reprod 2008; 79: 1135-1147. [Medline]

43. Nenci A, Becker C, Wullaert A, Gareus R, Loo G, Danese S, Huth M, Nikolaev A, Neufert C, Madison B, Gumucio D, Neurath MF, Pasparakis M. Epithelial NEMO links innate immunity to chronic intestinal inflammation. Nature 2007; 446: 557-561. [Medline]

44. Xavier RJ, Podolsky DK. Unravelling the pathogenesis of inflammatory bowel disease. Nature 2007; 448: 427-434. [Medline]

45. Allen JE, Wynn TA. Evolution of Th2 immunity: A rapid repair response to tissue de- structive pathogens. PLoS Pathog 2011; 7: e1002003. [Medline]

46. Yanagawa Y, Onoé K. Enhanced IL-10 production by TLR4- and TLR2-primed dendritic cells upon TLR restimulation. J Immunol 2007; 178: 6173-6180. [Medline]

47. Aliprantis AO, Yang RB, Mark MR, Suggett S, Devaux B, Radolf JD, Klimpel JD, Godowski P, Zychlinsky A. Cell activation and apoptosis by bacterial lipoproteins through Toll-like Receptor 2. Science 1999; 285: 736-739. [Medline]

48. Kiura K, Kataoka H, Yasuda M, Inoue N, Shibata K. The diacylated lipopeptide FSL-1 induces TLR2-mediated Th2 responses. FEMS Immunol Med Microbiol 2006; 48: 44-55. [Medline]

49. Dziarski R, Wang Q, Miyake K, Kirschning CJ, Gupta D. MD-2 enables Toll-like receptor 2 (TLR2)-mediated responses to lipopolysaccharide and enhances TLR2-mediated responses to gram-positive and gram-negative bacteria and their cell wall components. $J$ Immunol 2001; 166: 1938-1944. [Medline]

50. Moses T, Wagner L, Fleming SD. TLR4-mediated Cox2 expression increases intestina ischemia/reperfusion-induced damage. J Leukoc Biol 2009; 86: 971-980. [Medline]

51. Villamón E, Roig P, Gil ML, Gozalbo D. Toll-like receptor 2 mediates prostaglandin E2 production in murine peritoneal macrophages and splenocytes in response to Candida Albicans. Res Microbiol 2005; 156: 115-118. [Medline]

52. Arosh JA, Banu SK, Kimmins S, Chapdelaine P, MacLaren LA, Fortier MA. Effect of interferon- $\tau$ on prostaglandin biosynthesis, transport, and signaling at the time of maternal recognition of pregnancy in cattle: Evidence of polycrine actions of prostaglandin E2 Endocrinology 2004; 145: 5280-5293. [Medline]

53. Fahey JV, Wright JA, Shen L, Smith JM, Ghosh M, Rossoll RM, Wira CR. Estradio selectively regulates innate immune function by polarized human uterine epithelial cells in culture. Mucosal Immunology 2008; 1: 317-325. [Medline]

54. Jones LA, Anthony J, Henriquez FL, Lyons RE, Nickdel MB, Carter KC, Alexander J, Roberts CW. Toll-like receptor-4-mediated macrophage activation is differentially regulated by progesterone via the glucocorticoid and progesterone receptors. Immunology 2008; 125: 59-69. [Medline] 